\title{
Metabolism of high-density lipoproteins in cultured rat luteal cells
}

\author{
Valanila P. Rajan and K.M.J. Menon \\ Departments of Obstetrics and Gynecology and Biological Chemistry, University of Michigan Medical School, Ann Arbor, \\ MI (U.S.A.)
}

(Received 16 February 1987)

Key words: Lipoprotein metabolism; HDL degradation; Steroidogenesis; (Rat luteal cell)

The uptake of cholesterol from high-density lipoproteins (HDL) labeled with ${ }^{125} I$ and $\left.\mid{ }^{3} H\right]$ cholesterol was examined in cultured rat luteal cells. Luteal cells were incubated with labeled HDL, following which the metabolic fate of the apolipoproteins and cholesterol moieties of the receptor-bound HDL were examined. About 50\% of the originally bound HDL apolipoproteins were released into the medium in $24 \mathrm{~h}$ by a temperature-dependent process while only $5 \%$ of the HDL cholesterol was released unmetabolized. Inclusion of unlabeled HDL in the chase incubation resulted in increased release of apolipoprotein-derived radioactive products without significant change in the release of unmetabolized cholesterol. $60 \%$ of the apolipoproteinderived radioactivity could be precipitated with trichloroacetic acid; the remaining trichloroacetic acid-soluble radioactive fraction was identified as $\left[{ }^{125} I\right]$ iodotyrosine. Gel filtration chromatography of the chase-released material showed that the trichloroacetic acid-precipitable products, which contained no detectable amounts of cholesterol, eluted over a range of molecular sizes $(9-80 \mathrm{kDa})$. No intact HDL was retroendocytosed. About $80 \%$ of trichloroacetic acid-precipitable products could be immunoadsorbed on antiapolipoprotein A-I antibody immobilized on CNBr-activated Sepharose, suggesting the presence of fragments containing apolipoprotein A-I. This material was also capable of reassociating with native HDL. Lysosomal inhibitors were partially effective in inhibiting the amount of trichloroacetic acid-soluble products formed. The lysosomal degradation appeared to have no role in the uptake of HDL-derived cholesterol. These studies demonstrate preferential and total uptake of $\mathrm{HDL}$ cholesterol by luteal cells, with concomitant degradation of the lipoprotein.

\section{Introduction}

The role of plasma lipoproteins as a source of cholesterol in ovarian cells has been a subject of study by many laboratories, including ours [1-5]. Specific cell surface receptors have been identified for high- and low-density lipoproteins (HDL and

Abbreviations: HDL, high-density lipoprotein; LDL, low-density lipoprotein; CG, chorionic gonadotropin.

Correspondence: K.M.J. Menon, Department of Obstetrics and Gynecology, University of Michigan Medical School, Ann Arbor, MI 48109-0278, U.S.A.
LDL) in rat luteal cells [6,7] and both lipoproteins are equally effective in sustaining progesterone production [5]. However, important differences exist in the binding characteristics and further processing of LDL and HDL. LDL binding requires $\mathrm{Ca}^{2+}$ and is sensitive to heparin and proteinase whereas binding of $\mathrm{HDL}$ is insensitive to heparin and proteinases, and has no known ionic requirements [6]. The processing of $\mathrm{LDL}$ appears to involve receptor-mediated endocytosis, followed by lysosomal degradation by a process similar to that elucidated for the metabolism of this lipoprotein in cultured fibroblasts [8-10]. Unlike LDL, the degradation of HDL to trichloroacetic 
acid-soluble products occurs only to a small extent and the degradation does not account for all the HDL-derived cholesterol utilized for steroidogenesis [11-13]. Disparities between degradation of HDL and the amount of steroids produced have also been observed in adrenocortical cells [14]. Preferential uptake of cholesterol ethers from reconstituted HDL by hepatocytes and adrenals have also been reported $[15,16]$. Thus, it appears that different cell types could take up cholesterol from HDL by a mechanism not involving degradation of the apolipoprotein. In the present study, we have addressed the question of HDL metabolism in rat luteal cells by examining the processing of apolipoproteins and HDL-derived cholesterol. The results show that receptor-bound HDL is internalized by the luteal cells, and degraded HDL devoid of cholesterol is released as trichloroacetic acidsoluble and -insoluble products.

\section{Materials and Methods}

\section{Materials}

Molecular weight standards and agarose gel (Bio-Gel A-0.5m) were purchased from Bio-Rad Laboratories, Richmond, CA. Collagenase was the product of Cooper Biomedicals, Malvern, PA, and McCoy's medium was from GIBCO, Grand Island, NY. Bovine serum albumin (Fraction V), ovalbumin, dansylcadaverine and phenylmethylsulfonyl fluoride were obtained from Sigma Chemical Co., St. Louis, MO. Monospecific antihuman apolipoprotein A-I antibody was obtained from Boehringer-Mannheim Biochemicals, Indianapolis, IN, 3-iodotyrosine was from Aldrich Chemical Co., Milwaukee, WI, and 35-mm plastic tissue culture dishes were a product of Falcon Plastics, Oxnard, CA. Cyanogen bromide-activated Sepharose was from Pharmacia Fine Chemicals, Piscataway, NJ. $\left[1,2,6,7 \cdot{ }^{3} \mathrm{H}\right] \mathrm{Cholesterol}(70 \mathrm{Ci} /$ $\mathrm{mmol})$ and $\left[1,2,6,7-{ }^{3} \mathrm{H}\right]$ cholesteryl linoleate $(75$ Ci/mmol) were from New England Nuclear, Boston, MA. All other chemicals were purchased from Fisher Scientific Co., Detroit, MI.

\section{Animals and cell culture}

Luteal cell cultures were prepared from highly luteinized ovaries of 21-day-old Sprague-Dawley rats (Harlan Sprague-Dawley, Madison, WI) primed with pregnant mare serum gonadotropin and human chorionic gonadotropin (CG) as previously described $[12,13]$. Each culture dish contained cells equivalent to $600-700 \mu \mathrm{g}$ cellular protein. Before conducting the experiments described here, the serum-supplemented medium was removed and the cells were washed three times with McCoy's medium.

\section{Lipoproteins and labeling}

Human LDL (density, 1.02-1.063 g/ml) and $\mathrm{HDL}_{3}$ (density, $1.125-1.21 \mathrm{~g} / \mathrm{ml}$ ) were isolated from plasma of healthy donors by sequential ultracentrifugation after density adjustment with $\mathrm{KBr}$ as described by Havel et al. [17]. The absence of apolipoprotein $\mathrm{E}$ in the HDL was confirmed by SDS-polyacrylamide gel electrophoresis. HDL was labeled with ${ }^{125} \mathrm{I}$ by the iodine monochloride method of McFarlane [18], with some modifications [6], to a specific activity of $300-500$ $\mathrm{cpm} / \mathrm{ng}$ protein. Throughout this paper quantities of lipoproteins are expressed in terms of their protein content. Labeling with $\left[{ }^{3} \mathrm{H}\right]$ cholesterol was accomplished by a modification of the procedure of Jonas et al.'[19] as follows. $2 \mathrm{ml}$ of HDL in 0.15 $\mathrm{M} \mathrm{NaCl}$ (25 mg protein) were added to solvent-free $\left[{ }^{3} \mathrm{H}\right]$ cholesterol $(5 \mu \mathrm{Ci})$ and incubated at $37^{\circ} \mathrm{C}$ for $3 \mathrm{~h}$ with occasional mixing. The product was mixed with $20 \mathrm{ml}$ of density $1.21 \mathrm{KBr}$ solution and centrifuged at $100000 \times g$ for $24 \mathrm{~h}$. The top layer of labeled HDL was collected and dialyzed against three changes of $0.15 \mathrm{M} \mathrm{NaCl} / 0.1 \mathrm{mM}$ EDTA (pH 7.3). The resulting labeled HDL was analyzed for cholesterol, cholesteryl esters and protein, which were found to be present in proportions similar to unlabeled HDL. Thin-layer chromatography showed that the label was exclusively on the unesterified cholesterol. On gel filtration using a $10 \%$ agarose column the elution profile was superimposable with that of unlabeled HDL. The specific activity of the labeled HDL was 14000 $\mathrm{cpm} / \mu \mathrm{g}$ of unesterified cholesterol (or, 1400 $\mathrm{cpm} / \mu \mathrm{g}$ of total cholesterol).

$\left[{ }^{3} \mathrm{H}\right]$ Cholesteryl linoleate-labeled HDL was also prepared by the method described above using 10 $\mu \mathrm{Ci}$ of $\left[{ }^{3} \mathrm{H}\right]$ cholesteryl linoleate. The labeled $\mathrm{HDL}$ had a specific activity of $19000 \mathrm{cpm} / \mu \mathrm{g}$ of esterified cholesterol (or, $16000 \mathrm{cpm} / \mu \mathrm{g}$ of total cholesterol). 


\section{Determination of $H D L$ degradation}

Cultured luteal cells were preincubated with 10 $\mu \mathrm{g}$ of ${ }^{125} \mathrm{I}$-labeled HDL in $1 \mathrm{ml}$ of McCoy's medium at $37^{\circ} \mathrm{C}$ for $3 \mathrm{~h}$, unless otherwise stated. After removing the incubation medium, the cells were washed five times with $2-\mathrm{ml}$ aliquots of $\mathrm{Mc}$ Coy's medium to remove unbound ${ }^{125}$ I-labeled HDL. Further washing did not decrease the amount of cell-associated radioactivity. The cells were then incubated in $1 \mathrm{ml}$ of McCoy's medium for various time periods up to $24 \mathrm{~h}$. This second incubation is referred to as 'chase incubation'. At the time points indicated in tables and figures, the medium was aspirated and treated with $0.2 \mathrm{ml}$ of $2 \%$ bovine serum albumin (as a carrier), followed by $0.3 \mathrm{ml}$ of $50 \%$ trichloroacetic acid $(10 \%$ final concentration). After centrifugation at $3000 \times g$ for $20 \mathrm{~min}$, the pellet, representing larger peptides, was counted in a gamma counter. The supernatant was also counted to determine trichloroacetic acid-soluble radioactivity and then treated with $\mathrm{KI} / \mathrm{H}_{2} \mathrm{O}_{2}$, and extracted with chloroform/ methanol as described by Bierman et al. [20] to remove any inorganic iodide. The aqueous layer was counted to determine the amount of noniodide trichloroacetic acid-soluble products. There was no detectable amount of radioactive iodine in the organic layer. The cells were dissolved in 1.5 $\mathrm{ml}$ of $0.1 \mathrm{M} \mathrm{NaOH}$ by two extractions and the amount of cell-associated radioactivity was determined.

In experiments using $\left[{ }^{3} \mathrm{H}\right]$ cholesterol-labeled HDL, the cells were preincubated with the labeled lipoprotein and then reincubated, as described above, for $24 \mathrm{~h}$. The medium was collected and the cells were harvested and counted after adding scintillation fluid to determine the amount of cell-associated radioactivity. An aliquot of the incubation medium was assayed to determine the total amount of radioactivity released, and the remainder was extracted with petroleum ether and subjected to thin-layer chromatography as described [21]. The amount of sterols and progestins in the incubation medium were calculated from the results.

\section{Gel filtration chromatography}

Luteal cell cultures were preincubatcd with ${ }^{125}$ I-labeled HDL and chased in $1 \mathrm{ml}$ of McCoy's medium for $24 \mathrm{~h}$ as described above. The incubation medium was collected and chromatographed at room temperature on a $1.6 \times 90 \mathrm{~cm}$ column of $10 \%$ agarose equilibrated in a buffer containing $0.15 \mathrm{M} \mathrm{NaCl} / 0.3 \mathrm{mM}$ EDTA $/ 0.02 \% \mathrm{NaN}_{3} / 0.1 \%$ ovalbumin ( $\mathrm{pH} 7.5)$. The column was eluted with the same buffer and 2-ml fractions were collected. Ovalbumin was included in the buffer to maximize recovery. Omission of ovalbumin from the buffer did not affect the elution pattern. The column was calibrated using molecular weight standards as well as native LDL and HDL.

\section{Paper chromatography}

Fractions comprising the low-molecular-weight peak (see Fig. 5) from the gel filtration chromatography were combined and concentrated by lyophylization. The residue was dissolved in 0.5 $\mathrm{ml}$ of water and subjected to paper chromatography on a $20 \mathrm{~cm}$ long strip of Whatman No. 1 filter paper using $n$-butanol/acetic acid/water (100: $22: 50$ ) as described [22]. An authentic sample of 3-iodotyrosine was also chromatographed simultaneously as standard. The amino acid spots were visualized by ninhydrin spray and radioactivity was localized by counting 3-mm slices of the chromatogram.

\section{Immunoadsorption}

The amount of ${ }^{125}$ I-labeled apolipoprotein A-I present in the $24 \mathrm{~h}$ chase medium was quantitated by immunoadsorption to apolipoprotein A-I antibody-Sepharose. The affinity matrix was prepared by conjugating the apolipoprotein A-I antibody to cyanogen bromide-activated Sepharose following the manufacturer's instructions [23]. Prior to conjugation, the antibody preparation had been extensively dialyzed against the coupling buffer $(0.1$ $\mathrm{M} \mathrm{NaHCO}_{3} / 0.5 \mathrm{M} \mathrm{NaCl}, \mathrm{pH}$ 8.3). The coupling procedure involved treatment of $1 \mathrm{~g}$ of the cyanogen bromide-activated Sepharose with $2 \mathrm{ml}$ of the antiserum in $7 \mathrm{ml}$ of coupling buffer for 90 min, followed by blocking of the unoccupied sites on the matrix by incubating for $1 \mathrm{~h}$ in $0.1 \mathrm{M}$ Tris buffer ( $\mathrm{pH} 8$ ). The antibody-Sepharose thus prepared was stored at $4^{\circ} \mathrm{C}$ as a suspension in equal volume of $0.1 \mathrm{M}$ Tris- $\mathrm{HCl}$ buffer ( $\mathrm{pH} 7.5$ ) containing $0.15 \mathrm{M} \mathrm{NaCl} .500 \mu 1$ of this suspension contained sufficient antibody to bind $5 \mu \mathrm{g}$ of ${ }^{125} \mathrm{I}-$ 
labeled HDL. Immunoadsorption was carried out as follows. The antibody-Sepharose suspension $(500 \mu \mathrm{l})$ was poured into a vertically positioned disposable 2-ml syringe, the lower end of which was plugged with glass wool and connected to a peristaltic pump through a short length of Tygon tubing. After draining the buffer, $2 \mathrm{ml}$ of the $24 \mathrm{~h}$ chase medium containing degraded ${ }^{125}$ l-labeled HDL was added to the syringe and the eluate was recirculated using a peristaltic pump. After $30 \mathrm{~min}$ (by which time the adsorption was complete as determined in initial experiments), the recirculation was stopped and the eluate removed. The antibody-Sepharose was washed three times with 2

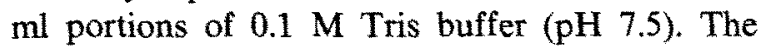
amounts of radioactivity in the Sepharose, eluate and washings were determined and the percentage of radioactivity bound to apolipoprotein A-I antibody was calculated.

\section{Other analytical procedures}

Protein contents of samples were determined by the method of Lowry et al. [24]. Cholesteryl and cholesteryl esters were determined by the method of Deacon and Dawson [25].

The data were analyzed by analysis of variance and Duncan's multiple range test. A value of $P<0.01$ was considered significant. Values are also expressed as means \pm S.E. where indicated.

\section{Results}

\section{Metabolism of HDL apolipoproteins by cultured luteal cells}

The initial experiments examined the fate of labeled apolipoprotein following binding of ${ }^{125} \mathrm{I}$ labeled HDL to luteal cells. Luteal cell cultures were incubated with $10 \mu \mathrm{g}$ of ${ }^{125} \mathrm{I}$-labeled HDL for $3 \mathrm{~h}$, washed to remove the unbound ${ }^{125} \mathrm{I}$-labeled HDL and reincubated in the absence of lipoproteins (chase). At 4, 18 and $24 \mathrm{~h}$, the medium from triplicate dishes was removed and precipitated with $10 \%$ trichloroacetic acid, and the cells were dissolved in $0.1 \mathrm{M} \mathrm{NaOH}$. Cell-associated, trichloroacetic acid-soluble and trichloroacetic acid-precipitable radioactivities were determined in each case. The results (Fig. 1) show that the cells progressively released radioactivity into the medium in such a way that by 24 h only about $50 \%$ of the originally bound ${ }^{125}$ I-labeled HDL remained associated with the cells. At any time point during the chase incubation, $60-65 \%$ of the radioactivity present in the medium was precipitable with $10 \%$ trichloroacetic acid. Inclusion of 300 -fold excess of unlabeled HDL in the incubation with ${ }^{125} \mathrm{I}$ labeled HDL inhibited the binding of ${ }^{125} \mathrm{I}$-labeled HDL, and this was further reflected in the lower amounts of radioactivity released into the medium during the chase incubation period (Fig. 1).

The possibility that the degradation of ${ }^{125} \mathrm{I}$ labeled HDL is due to nonspecific proteinases present in the incubation medium was examined by performing the above experiment in the presence of phenylmethylsulfonyl fluoride, a proteinase inhibitor. The results (data not presented) showed that phenylmethylsulfonyl fluoride had no effect on the degradation of ${ }^{125}$ I-labeled HDL.

The effect of incubation temperature on the release of cell-bound ${ }^{125}$ I-labeled HDL is shown in Fig. 2. The initial incubation with ${ }^{125}$ I-labeled HDL was performed at $37^{\circ} \mathrm{C}$ and the chase was carried out at either 37 or $4^{\circ} \mathrm{C}$. Cells incubated at $4^{\circ} \mathrm{C}$ released only $11 \%$ of the initially bound radioactivity in $24 \mathrm{~h}$ compared to $51 \%$ by the cells incubated at $37^{\circ} \mathrm{C}$, indicating that the release of cell-bound radioactivity is an energy-dependent process.

In the above experiments, the rate of release of ${ }^{125}$ I radioactivity from cells containing receptorbound ${ }^{125} \mathrm{~T}$-labeled HDL is somewhat faster during the initial hours of chase incubation. To determine whether the non-linearity of the rate of release is due to attainment of equilibrium between released and cell-associated radioactive material, the experiment shown in Table 1 was carried out. In the control experiment (Table I, column A), three sets of luteal cell cultures in triplicate were incubated with ${ }^{125} \mathrm{I}$-labeled HDL and chased in the absence of lipoproteins. The incubations were terminated at 4,18 or $24 \mathrm{~h}$ and the trichloroacetic acid-precipitable radioactivity in the medium was determined. Another set of triplicate dishes (Table I, column B) was incubated with ${ }^{125}$ I-labeled HDL under similar conditions, chased in the absence of lipoproteins, and the chase medium was replaced at 4 and $18 \mathrm{~h}$ intervals with fresh medium. The trichloroacetic acid precipitable radioactivity in the chase medium 

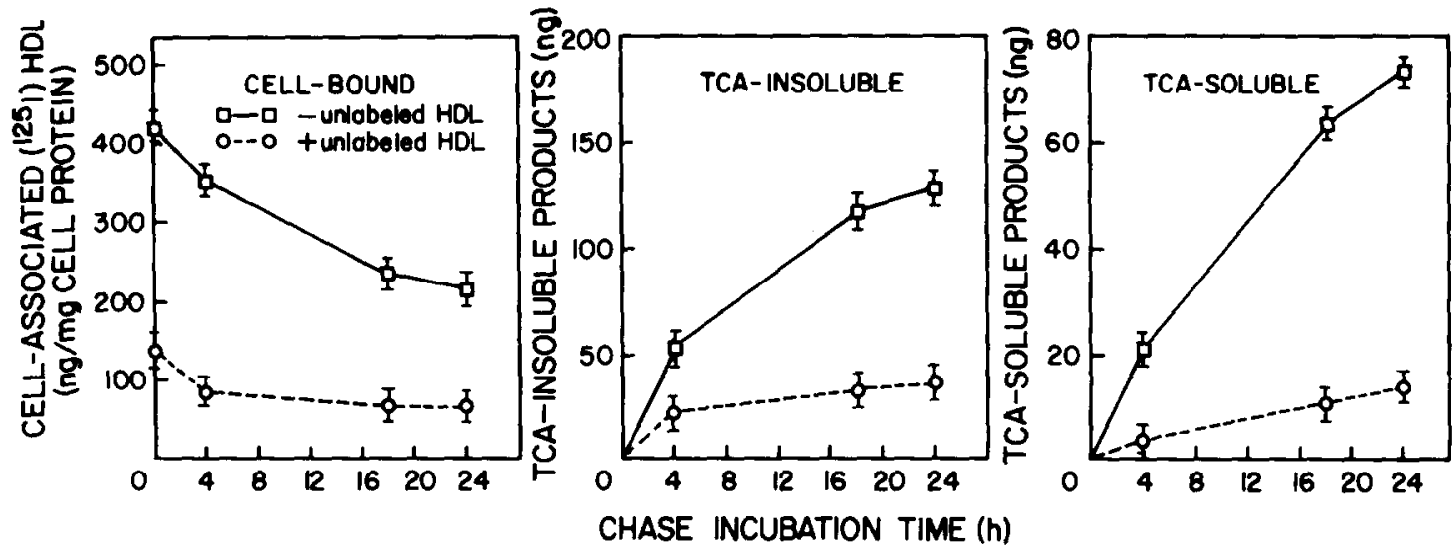

Fig. 1. Release of receptor-bound ${ }^{125}$ I-labeled HDL from luteal cells. Luteal cells were incubatcd with $10 \mu \mathrm{g} / \mathrm{ml}$ of ${ }^{125} \mathrm{I}-\mathrm{labeled} \mathrm{HDL}$ in the absence ( $\square$ ) and presence $(O)$ of a 300-fold excess of unlabeled HDL for $3 \mathrm{~h}$, washed and reincubated in the absence of HDL. Cell-associated as well as trichloroacetic acid (TCA) -precipitable and trichloroacetic acid-soluble radioactivity in the medium were determined at the indicated time points. Values are means \pm S.E. of triplicate determinations.

was determined at 4,18 and $24 \mathrm{~h}$ intervals. Examination of data (Table I) revealed that replacing the incubation medium with fresh medium had no effect in the total amount of trichloroacetic acidprecipitable radioactivity released. The data indicate that the non-linearity of the release of trichloroacetic acid-precipitable radioactivity was not due to equilibration between radioactivity materials within the cells and in the medium.

The effect of inclusion of unlabeled HDL in the chase medium on the release of cell-associated radioactivity is shown in Fig. 3 (upper panels). The cells were incubated with ${ }^{125}$ I-labeled HDL for $3 \mathrm{~h}$, washed and reincubated in the absence or presence of $10 \mu \mathrm{g}$ of unlabeled HDL for periods up to $24 \mathrm{~h}$. The results showed that the amount of trichloroacetic acid-precipitable radioactivity released was higher when unlabeled HDL was present during the chase. The increase in trichloroacetic acid-precipitable radioactivity was reflected in lower cell-associated and trichloroacetic acidsoluble radioactivity. Similar experiments using unlabeled LDL in the chase incubation medium (Fig. 3, middle panels) yielded slightly different results. The increase in the amount of trichloroacetic acid-precipitable radioactivity was not as
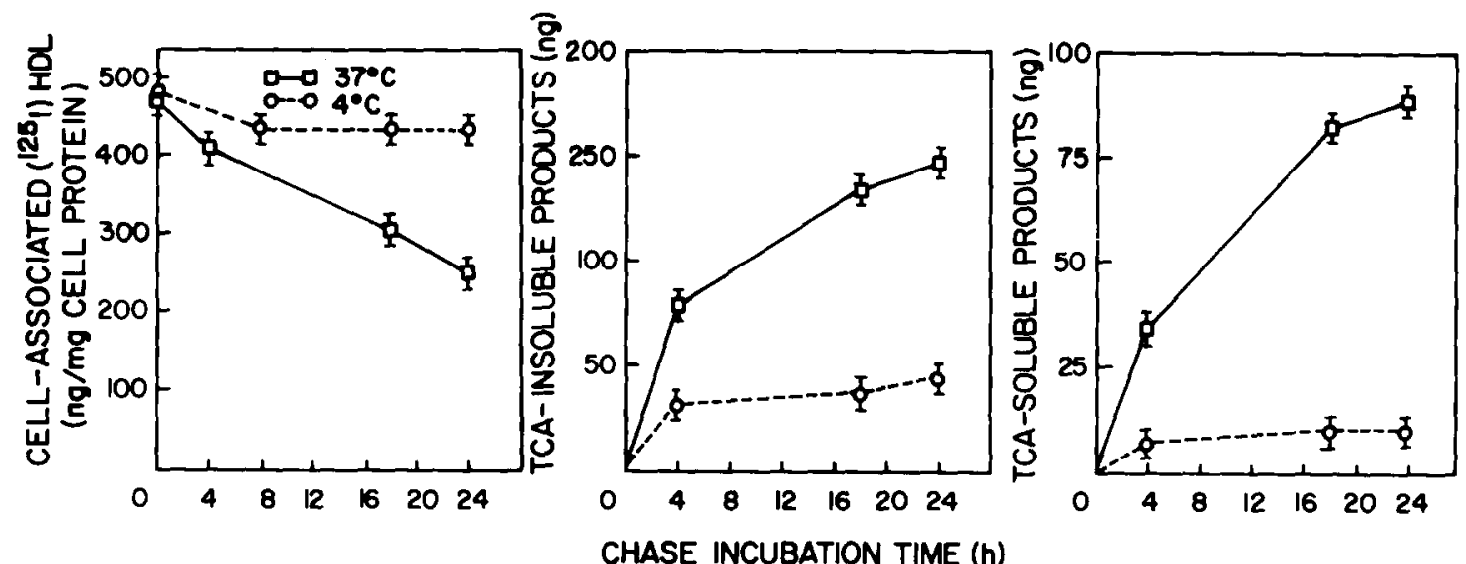

Fig. 2. Effect of low temperature on the release of cell-associated ${ }^{125} \mathrm{I}$-labeled HDL. Luteal cells were incubated with ${ }^{225} \mathrm{I}$-labeled $\mathrm{HDL}$ at $37^{\circ} \mathrm{C}$, chased in lipoprotein-free medium at either $37(\square)$ or $4^{\circ} \mathrm{C}(\mathrm{O})$ and cell-associated, trichloroacetic acid (TCA) -precipitable and trichloroacetic acid-soluble radioactivity were determined after the indicated time periods. Values are means \pm S.E. of triplicate determinations. 

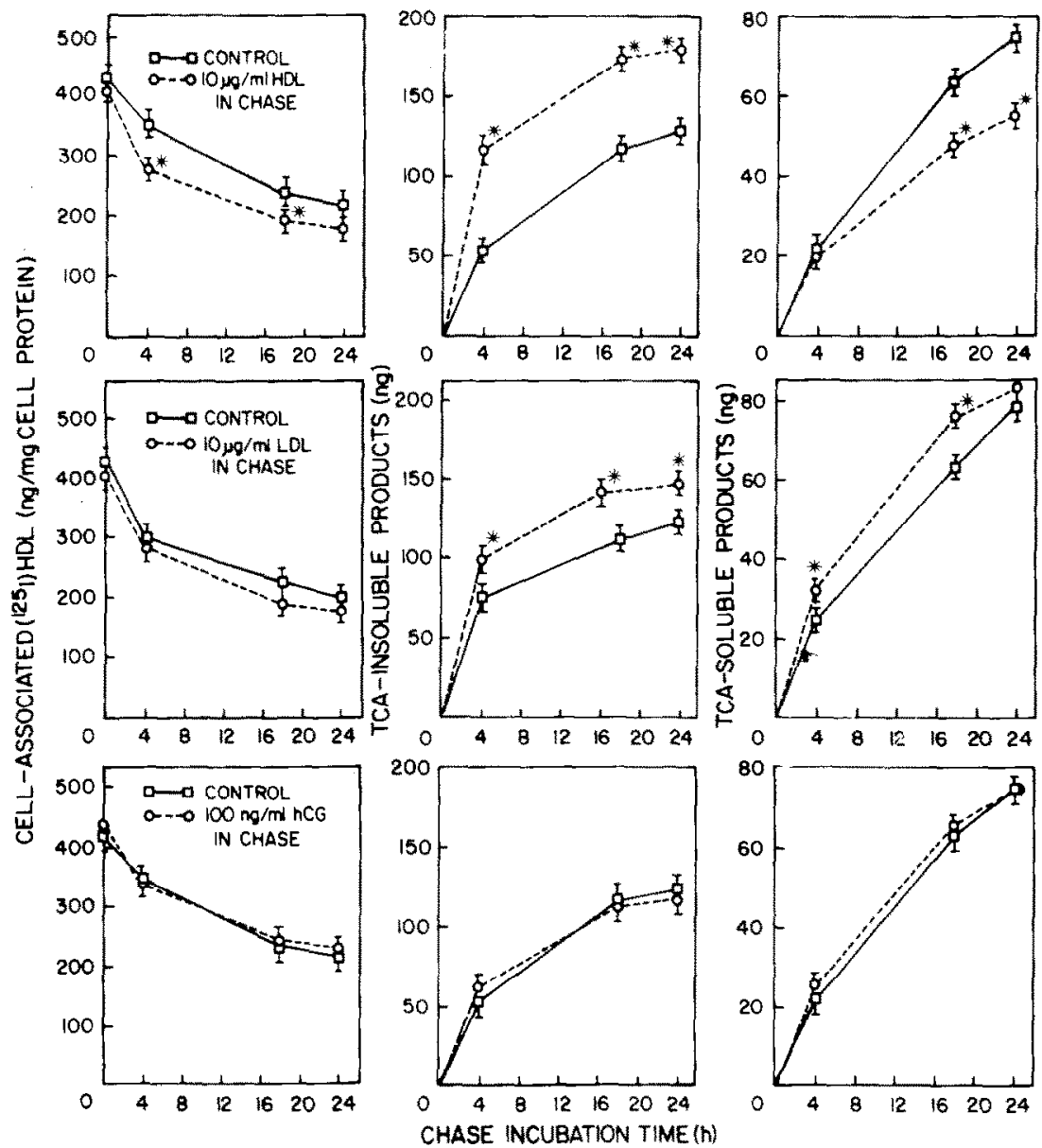

Fig. 3. Effect of unlabeled HDL, LDL and human $\mathrm{CG}$ in the chase medium on the release of radioactivity from luteal cells containing receptor-bound ${ }^{125} \mathrm{I}$-labeled HDL. Cells were incubated for $3 \mathrm{~h}$ with $10 \mu \mathrm{g} / \mathrm{ml}{ }^{125} \mathrm{I}$-labeled HDL, washed and chased in the absence ( $D$ ) and presence $(O)$ of the indicated concentrations of unlabeled HDL, LDL and human CG. Cell-associated, trichloroacetic acid (TCA)-precipitable and trichloroacetic acid-soluble radioactivity were determined at the indicated time points.

Values are means \pm S.E. of triplicate determinations. ${ }^{*}$ Significantly different from control, $P<0.01$.

high as that obtained using unlabeled HDL, and, unlike HDL, there was an increase in the amount of trichloroacetic acid-soluble radioactivity. Inclusion of human CG in the chase incubation medium (Fig. 3, lower panels) had no detectable effect on the composition of the chase incubation medium. These results suggest that the presence of unlabeled HDL in the medium enhanced the processing of the lipoproteins, resulting in the release of a larger amount of radioactivity.

Determination of the effect of increasing amounts of unlabeled HDL in the chase medium on the release of radioactivity from cells initially labeled with ${ }^{125}$ I-labeled HDL showed that the release of radioactivity increased in a concentration-dependent manner (Table II). At the highest concentration of HDL used $(200 \mu \mathrm{g})$, more than $75 \%$ of the initially bound radioactivity was released during the $24 \mathrm{~h}$ incubation, compared to less than $50 \%$ in the absence of HDL, and most of the increase was due to increase of trichloroacetic acid-precipitable products released. This experiment showed that the rate of processing of HDL in luteal cells is dependent on the concentration of HDL in the medium.

Next, we examined whether inhibitors of internalization and lysosomal function had any effect on the release of cell-bound ${ }^{125}$ I-labeled HDL 
TABLE I

EFFECT OF REPLACING THE CHASE INCUBATION MEDIUM AT INTERVALS ON THE RELEASE OF TRICHLOROACETIC ACID-PRECIPITABLE RADIOACTIVITY INTO THE MEDIUM

Luteal cell cultures in triplicate were incubated with ${ }^{125}$ I-labeled HDL for $3 \mathrm{~h}$, washed and chased in IIDL-free medium. In one set of dishes (column B), the medium was replaced with fresh medium at the indicated time points. The cumulative amounts of trichloroacetic acid-precipitable radioactivity released by the cells are shown in column B. Values in column A were obtained from three sets of triplicate dishes (one for each time point) which were incubated in the same chase medium throughout the incubation time $(4,8$ or $24 \mathrm{~h})$. Values are means $\pm S$.E.

\begin{tabular}{lll}
\hline $\begin{array}{l}\text { Chase incubation } \\
\text { time }(\mathrm{h})\end{array}$ & $\begin{array}{l}\text { Total trichloroacetic acid-precipitable } \\
\text { radioactivity released into the medium } \\
(\mathrm{ng} / \mathrm{mg} \text { cell protein) }\end{array}$ \\
\cline { 2 - 3 } & $\mathrm{A}$ & $\mathrm{B}$ \\
\hline 4 & $43.9 \pm 1.5$ & $41.0 \pm 1.4$ \\
18 & $89.9 \pm 6.7$ & $86.1 \pm 0.4$ \\
24 & $103.2 \pm 1.3$ & $97.8 \pm 2.1$ \\
\hline
\end{tabular}

(Fig. 4). In this experiment, $50 \mu \mathrm{M}$ dansylcadaverinc, an inhibitor of receptor-mediated endocytosis, was included in the initial incubation of luteal cells with ${ }^{125}$ I-labeled HDL, following which the cells were washed and chased for up to $24 \mathrm{~h}$ in the continued presence of the inhibitor. The inhibitor had no effect on the amount of cell-bound, trichloroacetic acid-precipitable and trichloro-
TABLE II

EFFECT OF UNLABELED HDL ON THE RELEASE OF RADIOACTIVITY FROM LUTEAL CELLS CON. TAINING RECEPTOR-BOUND ${ }^{125}$ I-LABELED HDL

Luteal cells containing receptor-bound ${ }^{125}$ I-labeled HDL were incubated with the indicated concentrations of unlabeled HDL for $24 \mathrm{~h}$ at $37^{\circ} \mathrm{C}$ and the amount of trichloroacetic acid-prccipitable and trichloroacetic acid-soluble radioactivity in the medium were determined. Values are means \pm S.E. of triplicate determinations. Values are expressed as a percent of the total cell-associated radioactivity at the beginning of the incubation.

\begin{tabular}{lll}
$\begin{array}{l}\text { Unlabeled HDL } \\
\text { in chase } \\
\text { incubation }(\mu \mathrm{g} / \mathrm{ml})\end{array}$ & $\begin{array}{l}\text { Trichloroacetic } \\
\text { acid-insoluble } \\
\text { radioactivity }\end{array}$ & $\begin{array}{l}\text { Trichloroacetic } \\
\text { acid-soluble } \\
\text { radioactivity }\end{array}$ \\
\hline 0 & $24.2 \pm 1.6$ & $19.1 \pm 1.2$ \\
10 & $44.4 \pm 0.9$ & $12.3 \pm 0.5$ \\
50 & $52.1 \pm 1.1$ & $11.0 \pm 0.9$ \\
100 & $56.9 \pm 4.5$ & $12.1 \pm 0.3$ \\
200 & $61.0 \pm 3.4$ & $12.0 \pm 0.4$ \\
\hline
\end{tabular}

acetic acid-soluble radioactivity when compared to control, suggesting that receptor-mediated endocytosis may not be involved in the metabolism of HDL in luteal cells. Similar experiments in the presence of $50 \mathrm{mM} \mathrm{NH}_{4} \mathrm{Cl}$, an inhibitor of lysosomal function, showed partial inhibition of the appearance of trichloroacetic acid-soluble radioactivity (Fig. 4), suggesting that at least a part of the degradation of ${ }^{125}$ I-labeled HDL might take place in the lysosomes. Ammonium chloride did not affect the amount of cell-bound radioactivity dur-
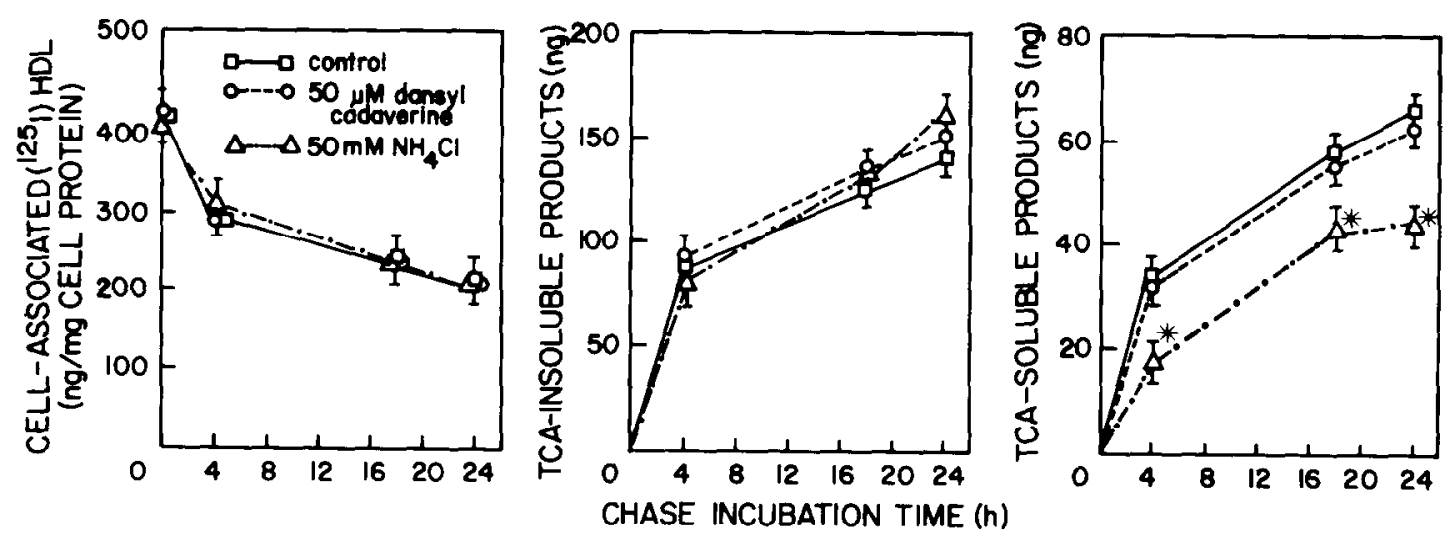

Fig. 4. Effect of $50 \mu \mathrm{M}$ dansylcadaverine $(O)$ and $50 \mathrm{mM} \mathrm{NH}_{4} \mathrm{Cl}(\Delta)$ on the release of receptor-bound ${ }^{125}$ I-labeled $\mathrm{HDL}$ from luteal cells. Cells were incubated for $3 \mathrm{~h}$ with ${ }^{125} \mathrm{I}$-labeled HDL and chased for up to $24 \mathrm{~h}$ in lipoprotein-free medium. Inhibitors, when used, were present in both the incubations. Values are means \pm S.E. of triplicate determinations. * Significantly different from control, $P<0.01$. $\square$, control; TCA, trichloroacetic acid. 
ing the $24 \mathrm{~h}$ of incubation. A slight increase in the amount of trichloroacetic acid-precipitable radioactivity, although consistently observed, was not statistically significant. Two other lysosomal inhibitors, chloroquine $(100 \mu \mathrm{M})$ and leupeptin (1 $\mathrm{mM}$ ), also partially inhibited the formation of trichloroacetic acid-soluble products.

\section{Characterization of ${ }^{125}$ I-labeled HDL degradation products}

The nature of the radioactive products released during the chase period by luteal cells preincubated with ${ }^{125}$ I-labeled HDL were analyzed by gel filtration chromatography. The chase medium containing radioactive products released by the cells was chromatographed on a $10 \%$ agarose column $(1.6 \times 90 \mathrm{~cm})$ equilibrated with buffer containing $0.1 \%$ ovalbumin and fractions of the eluate were analyzed for ${ }^{125} I$ radioactivity. The sharp peak near the column total volume (Fig. 5) accounted for $41 \%$ of the total amount of radioactivity eluted from the column. The remainder of the radioactivity was eluted over a molecular size range of $9-80 \mathrm{kDa}$, but no intact ${ }^{125} \mathrm{I}$-labeled HDL was present. Fractions comprising the lowmolecular-weight peak (Fig. 5) were combined, concentrated by lyophylization and analyzed by paper chromatography. Greater than $96 \%$ of the radioactivity migrated as a single spot with $R_{F}$ 0.62 , which was identical to the $R_{\mathrm{F}}$ value of an authentic sample of 3-iodotyrosine.

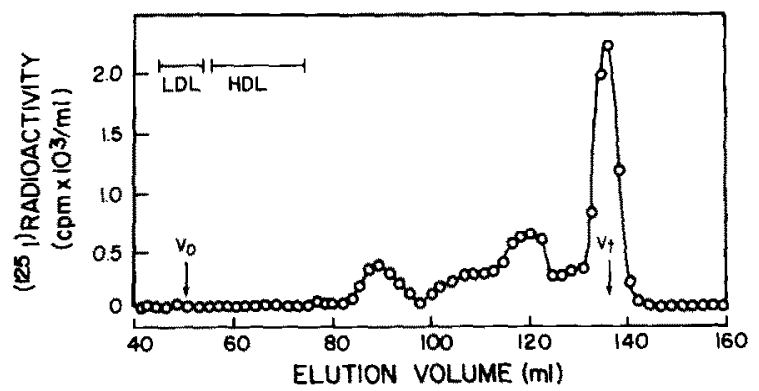

Fig. 5. Gel filtration of chase-released ${ }^{125}$ I-labeled HDI. The $24 \mathrm{~h}$ chase medium containing radioactivity released by cells preincubated with ${ }^{125}$ I-labeled HDL was chromatographed on a $1.6 \times 90 \mathrm{~cm}$ column of $10 \%$ agarose gel equilibrated with 0.3 mM EDTA buffer (pH 7.5) containing $0.15 \mathrm{M} \mathrm{NaCl}, 0.02 \%$ $\mathrm{NaN}_{3}$ and $0.1 \%$ ovalbumin and eluted with the same buffer. $2-\mathrm{ml}$ fractions were collected and the radioactivity was determined.
As a control for the above experiment, ${ }^{125} \mathrm{I}-$ labeled HDL was incubated for $24 \mathrm{~h}$ with 'conditioned medium' (medium recovered from luteal cell cultures incubated overnight in the absence of any additives) and subjected to gel filtration analysis. The elution profile of the incubated HDL was similar to the starting HDL, showing that degradation had not occurred in the absence of cells (data not shown).

In initial experiments in which ovalbumin was not included in the elution buffer, the recovery of radioactivity following agarose chromatography was $75-80 \%$. In an attempt to improve the recovery, unlabeled HDL was mixed as a carrier with the test sample before subjecting to gel chromatography. The addition of unlabeled $\mathrm{HDL}$ changed the elution pattern and most of the higher

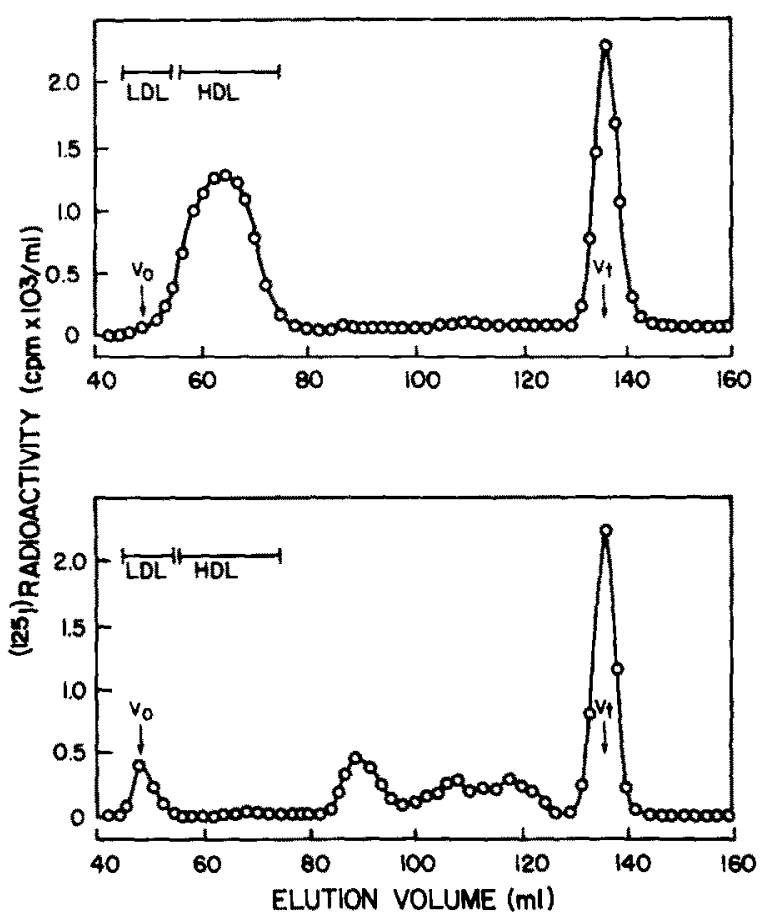

Fig. 6. Effect of carrier unlabeled HDL on the elution profile of radioactivity released by luteal cells preincubated with ${ }^{125} \mathrm{I}$. labeled HDL. The 24 h chase medium containing released radioactivity was mixed with $200 \mu 1$ of unlabeled HDL (upper panel) or unlabeled LDL (lower panel) and chromatographed on a $1.6 \times 90 \mathrm{~cm}$ column of $10 \%$ agarose gel equilibrated with $0.3 \mathrm{mM}$ EDTA buffer ( $\mathrm{pH} 7.5$ ) containing $0.15 \mathrm{M} \mathrm{NaCl}, 0.02 \%$ $\mathrm{NaN}_{3}$ and $0.1 \%$ ovalbumin and eluted with the same buffer. $2-\mathrm{ml}$ fractions were collected and the radioactivity was determined. 
molecular weight radioactive fragments co-eluted with the native HDL. Similar co-elution of radioactivity with native HDL occurred even when $0.1 \%$ ovalbumin was present in the elution buffer (Fig. 6, upper panel). The [ ${ }^{125}$ I]iodotyrosine peak was unaffected by the presence of native HDL. The reassociation of ${ }^{125}$ I-labeled HDL fragments with native $\mathrm{HDL}$ appears to be a specific process since use of unlabeled LDL as a carrier affected the elution profile only to a small extent (Fig. 6, lower panel).

Further characterization of the nature of radioactive protein components released during the chase incubation of luteal cells containing receptor-bound ${ }^{125}$ I-labeled HDL was carried out by immunoadsorption. On treatment of the $24 \mathrm{~h}$ chase medium with apolipoprotein A-I antibody-Sepharose (see Materials and Methods), $47 \%$ of the radioactivity was adsorbed by the antibody (Table III), suggesting that the medium contained fragments of HDL bearing intact apolipoprotein A-I. The incubation medium after treatment with apolipoprotein A-I antibody-Sepharose was subjected to trichloroacetic acid precipitation (Table

\section{TABLE III}

\section{IMMUNOADSORPTION OF THE $24 \mathrm{~h}$ CHASE MEDIUM} TO APOLIPOPROTEIN A-I ANTIBODY-SEPHAROSE

In experiment 1 , the $24 \mathrm{~h}$ chase incubation medium from luteal cells preincubated with ${ }^{125}$ I-labeled HDL was subjected to immunoadsorption to apolipoprotcin A-I antibody-Sepharose as described in Materials and Methods, and the unadsorbed material plus two washings were precipitated with $10 \%$ trichloroacetic acid. In experiment 2 , the $24 \mathrm{~h}$ chase medium was directly precipitated with $10 \%$ trichloroacetic acid. Values are means $\pm S . E$. of triplicate determinations.

\begin{tabular}{lll}
\hline & $\mathrm{cpm}$ & $\%$ \\
\hline $\begin{array}{l}\text { Experiment } 1 \\
\text { total radioactivity in chase } \\
\quad \text { medium }\end{array}$ & $12700 \pm 200$ & $100 \pm 1.6$ \\
$\begin{array}{l}\text { adsorbed on apolipoprotein A-I } \\
\text { antibody-Sepharose } \\
\text { trichloroacetic acid-precipitable } \\
\text { in medium }\end{array}$ & $5940 \pm 80$ & $47 \pm 0.6$ \\
$\begin{array}{l}\text { Experiment } 2 \\
\text { total radioactivity in chase } \\
\quad \text { medium }\end{array}$ & $1520 \pm 40$ & $12 \pm 0.3$ \\
$\begin{array}{c}\text { total trichloroacetic acid- } \\
\text { precipitable }\end{array}$ & $11430 \pm 190$ & $100 \pm 1.7$ \\
\hline
\end{tabular}

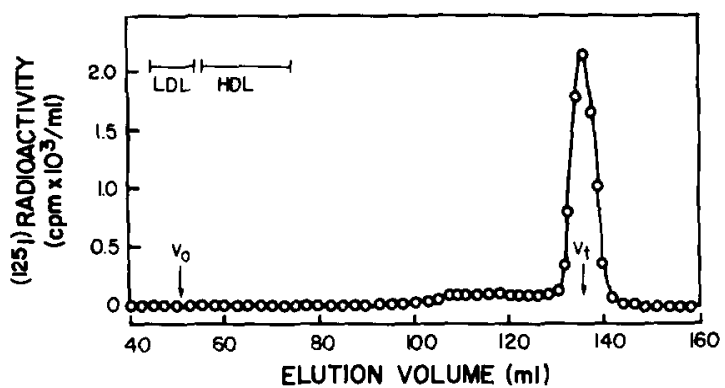

Fig. 7. Chromatography of the $24 \mathrm{~h}$ chase medium from which immunoadsorbable materials have been removed by treatment with apolipoprotein A-I antibody-Sepharose. The chase medium after removal of immunoadsorbable materials was chromatographed on a $1.6 \times 90 \mathrm{~cm}$ column of $10 \%$ agarose gel equilibrated with $0.3 \mathrm{mM}$ EDTA buffer ( $\mathrm{pH} 7.5$ ) containing $0.15 \mathrm{M} \mathrm{NaCl}, 0.02 \% \mathrm{NaN}_{3}$ and $0.1 \%$ ovalbumin and eluted with the same buffer. 2-ml fractions were collected and the radioactivity was determined.

\section{TARI, IV}

\section{RELEASE OF APOLIPOPROTEINS AND CHOLESTEROL FROM CELLS PREINCUBATED WITH HDL}

Luteal cells preincubated with $\left[{ }^{3} \mathrm{H}\right]$ cholesterol- or $\left[{ }^{3} \mathrm{H}\right]$ cholesteryl linoleate-labeled HDL were chased for $24 \mathrm{~h}$ in the presence of $0-200 \mu \mathrm{g}$ of unlabeled HDL and the amount of radioactivity released into the medium was determined. Release of apolipoprotein degradation products was measured in parallel experiments in which the cells were preincubated with ${ }^{125}$ I-labeled HDL. The amounts of radioactive products released during the chase is expressed as a percentage of the initial cell-associated radioactivity at $0 \mathrm{~h}$. Results are means \pm S.E. of triplicate determinations.

\begin{tabular}{|c|c|c|}
\hline $\begin{array}{l}\text { Amount of } \\
\text { unlabeled } \mathrm{HDL} \\
\text { in chase }(\mu \mathrm{g})\end{array}$ & $\begin{array}{l}\text { Percent of originally } \\
\text { bound HDL apolipo- } \\
\text { proteins released }^{3}\end{array}$ & $\begin{array}{l}\text { Percent of the origi- } \\
\text { nally bound HDL } \\
\text { cholesterol released }^{b}\end{array}$ \\
\hline \multicolumn{3}{|c|}{ Cells treated with $\left[{ }^{3} \mathrm{H}\right]$ cholesterol-labeled HDL } \\
\hline 0 & $47 \pm 2$ & $22 \pm 1$ \\
\hline 10 & $56 \pm 3$ & $25 \pm 2$ \\
\hline 50 & $63 \pm 1$ & $27 \pm 1$ \\
\hline 100 & $69 \pm 2$ & $23 \pm 3$ \\
\hline 200 & $73 \pm 2$ & $37 \pm 2$ \\
\hline
\end{tabular}

Cells treated with [ ${ }^{3} \mathrm{H}$ ]cholesteryl linoleate-labeled HDL

$\begin{array}{rll}0 & 46 \pm 3 & 21 \pm 1 \\ 10 & 56 \pm 3 & 23 \pm 2 \\ 50 & 65 \pm 2 & 26 \pm 2 \\ 100 & 70 \pm 3 & 27 \pm 1 \\ 200 & 76 \pm 2 & 34 \pm 3\end{array}$

a Total radioactivity bound at $0 \mathrm{~h}=460 \pm 30 \mathrm{ng}$ of $\mathrm{HDL}$ apolipoprotein.

b Total radioactivity bound at $0 \mathrm{~h}=180 \pm 15 \mathrm{ng}$ of total HDL cholesterol. 
III). The amount of radioactivity precipitated by trichloroacetic acid was $12 \%$ of that present in the original chase medium and represents radioactive peptides that did not bind to apolipoprotein A-I antibody-Sepharose. Direct trichloroacetic acid precipitation of the chase medium (before treatment with apolipoprotein A-I antibody-Sepharose) resulted in precipitation of $58 \%$ of the radioactivity (Table III), which is consistent with the total amount of peptides determined by immunoadsorption (47\%) followed by trichloroacetic acid precipitation (12\%).

Finally, the chase medium which had been subjected to immunoadsorption with apolipoprotein A-I antibody-Sepharose was analyzed by agarose gel chromatography (Fig. 7). The small amount of trichloroacetic acid-precipitable peptides eluted over a wide range of molecular sizes, but were smaller fragments than the immunoreactive fragments. These probably represent fragments containing apolipoproteins other than apolipoprotein A-I or partial degradation products of the latter from which the antibody-recognizing moiety has been lost. These experiments show that HDL apolipoproteins are processed and partially degraded by the luteal cells.

\section{Metabolism of HDL cholesterol}

The metabolism of HDL-derived cholesterol in luteal cells was examined in experiments using HDL labeled with (1) $\left[{ }^{3} \mathrm{H}\right]$ cholesterol or (2) $\left[{ }^{3} \mathrm{H}\right]$ cholesteryl linoleate (Tables IV and V). Luteal cells pretreated with $\left[{ }^{3} \mathrm{H}\right]$ cholesterol-labeled $\mathrm{HDL}$ or $\left[{ }^{3} \mathrm{H}\right]$ cholesteryl linolcate-labeled HDL werc incubated for $24 \mathrm{~h}$ in the presence of $0-200 \mu \mathrm{g}$ of unlabeled HDL. At the end of the incubation, radioactivity associated with the cells and in the medium was determined. The medium was also analyzed by thin-layer chromatography to determine the nature of the released radioactive products. Parallel experiments using cells pretreated with ${ }^{125}$ I-labeled HDL also were conducted to determine the amount of apolipoproteins released. Data presented in Table IV show that with increasing amounts of unlabeled HDL in the chase incubation, the release of apolipoprotein-derived radioactivity was increased. With the highest amount of unlabeled HDL used $(200 \mu \mathrm{g})$ about $75 \%$ of the originally

\section{TABLE V}

COMPOSITION OF RADIOACTIVE PRODUCTS RELEASED BY LUTEAL CELLS PREINCUBATED WITH $\left[{ }^{3} \mathrm{H}\right]$ CHOLESTEROL-LABELED HDL

Luteal cells preincubated with $\left[{ }^{3} \mathrm{H}\right] \mathrm{cholesterol-}$ or $\left[{ }^{3} \mathrm{H}\right]$ cholesteryl linoleate-labeled HDL were chased for $24 \mathrm{~h}$ in the presence of $0-200 \mu \mathrm{g}$ of unlabeled HDL. The chase medium containing released radioactivity was analyzed by thin-layer chromatography as described in Materials and Methods. Numbers in parenthesis indicate percent of initially bound radioactivity released in total cholesterol and progestin fractions.

\begin{tabular}{|c|c|c|c|c|}
\hline \multirow{2}{*}{$\begin{array}{l}\text { Amount of } \\
\text { unlabcled } \mathrm{HDL} \\
\text { in chase }(\mu \mathrm{g})\end{array}$} & \multicolumn{4}{|c|}{$\begin{array}{l}\text { Composition of radioactive products } \\
\text { rcleased ( } \mathrm{ng} / \mathrm{mg} \text { cell protein) }\end{array}$} \\
\hline & $\begin{array}{l}\text { choles- } \\
\text { terol }\end{array}$ & $\begin{array}{l}\text { choles- } \\
\text { teryl } \\
\text { esters }\end{array}$ & $\begin{array}{l}\text { total } \\
\text { cholesterol }\end{array}$ & progestins \\
\hline \multicolumn{5}{|c|}{ Cells treated with $\left[{ }^{3} \mathrm{H}\right]$ cholesterol-labeled $\mathrm{HDL}$} \\
\hline 0 & 7.0 & 2.0 & $9.0(5)$ & $30.6(17)$ \\
\hline 10 & 9.0 & 1.8 & $10.8(6)$ & $34.2(19)$ \\
\hline 50 & 6.3 & 0.9 & $7.2(4)$ & $41.4(23)$ \\
\hline 100 & 7.7 & 1.4 & $9.1(5)$ & $32.4(18)$ \\
\hline 200 & 17.6 & 4.1 & $21.7(12)$ & $45.0(25)$ \\
\hline \multicolumn{5}{|c|}{ Cells treated with $\left[{ }^{3} \mathrm{H}\right]$ cholesteryl linoleate-labeled HDL } \\
\hline 0 & 0.6 & 6.7 & $7.3(4)$ & $29.0(17)$ \\
\hline 10 & 0.9 & 4.1 & $5.0 \quad(3)$ & $35.3(20)$ \\
\hline 50 & 2.2 & 2.9 & 5.1 & $39.1(23)$ \\
\hline 100 & 5.0 & 6.3 & $11.3 \quad(6)$ & $36.5(21)$ \\
\hline 200 & 7.6 & 6.3 & $13.9 \quad(5)$ & $47.9(29)$ \\
\hline
\end{tabular}

bound ${ }^{125} \mathrm{I}$ label was released, compared to $50 \%$ in the absence of HDL. In comparison, the amount of cholesterol-derived radioactivity released during $24 \mathrm{~h}$ comprised only $21-37 \%$ of the originally bound label (Table IV). Analysis of the incubation medium by thin-layer chromatography (Table V) showed that $75-90 \%$ of the released radioactivity was in the form of progestins; the remainder was a mixture of labeled cholesterol and cholesteryl esters. Gel filtration analysis of the chase medium showed that all the radioactivity was eluted as a single peak near the column total volume (data not shown), indicating that the released cholesterol is not associated with the larger degradation products of HDL. This experiment showed that both free cholesterol and cholesterol esters associated with HDL are utilized for steroidogenesis, and that concentration of HDL in the medium has moderate effects on the rate of processing of the 
sterols. In summary, the results presented in Tables IV and V indicate that HDL is intracellularly processed by luteal cells and the cholesterol is retained and utilized for steroidogenesis while the apoliprotein constituents are effluxed into the medium.

\section{Discussion}

The present studies have shown that HDL is intracellularly processed by luteal cells and that degradation of the HDL particle occurs during cholesterol uptake. The products of degradation of HDL appeared as both trichloroacetic acid-soluble and -precipitable fragments. Analysis of the chase medium by gel filtration showed that the higher-molecular-weight, trichloroacetic acid-precipitable radioactive materials released by the cells eluted over a wide range of molecular sizes. The largest particles released had a particle size of 80 $\mathrm{kDa}$, which corresponds to less than one-third the size of the intact HDL used in this study. The absence of intact HDL in the medium suggests that retroendocytosis of HDL may not occur in these cells. However, $80 \%$ of the trichloroacetic acid-precipitable radioactivity was adsorbed by apolipoprotein A-I antibody-Sepharose. Since the peptides recognized by the antibody were eluted over a range of molecular sizes on gel filtration, it would be reasonable to assume that those fractions with a molecular size larger than apolipoprotein A-I (i.e., $25-80 \mathrm{kDa}$ ) contain partially degraded HDL particles. Interestingly, when the chase medium was mixed with carrier unlabeled HDL and subjected to gel filtration analysis, most of the radioactivity representing trichloroacetic acid-precipitable products co-eluted with the native HDL. This reassociation appeared to be a specific process since use of LDL as a carrier did not result in similar co-elution. The results of this study are consistent with the idea that HDL delivers cholesterol to luteal cells without undergoing complete degradation to trichloroacetic acidsoluble products. A portion of the apolipoproteins, either free or associated with a small amount of lipids, is released from the cell in immunologically intact form. Under in vivo conditions the released material could interact with plasma lipoproteins and reform into HDL particles. The abil- ity of the immunoprecipitable products in the chase medium to associate with native HDL supports this contention. Preferential release of protein-bound radioactivity and retention of lipid components in human aortic smooth muscle cells preincubated with ${ }^{125}$ I-labeled lipoprotein (VLDL and LDL) has been reported by Filipovic and Buddecke [27]. About one-half of the released radioactivity was trichloroacetic acid-precipitable. These authors also found that bovine aortic smooth muscle cells labeled with ${ }^{125}$ I-labeled HDL or ${ }^{125}$ I-labeled LDL released radioactivity into the medium, $35-40 \%$ of which was precipitable with specific anti-HDL and anti-LDL sera [28]. These observations are consistent with our results.

The uptake of HDL appeared to be independent of internalization via coated pits since dansylcadaverine, a tranglutaminase inhibitor, had no effect on the release of radioactive products. Electron microscopic examination of the uptake of HDL in perfused rat ovary by Paavola and Strauss [29] also showed a lack of association of the label with bristle-coated areas of the plasma membranes. Lysosomotropic agents inhibited degradation of ${ }^{125}$ I-labeled HDL to trichloroacetic acidsoluble products, but had no detectable effect on the release of trichloroacetic acid-precipitable products. In this regard, Marshall [26] has found that retroendocytosis of insulin from adipocytes was unaffected by the lysosomal inhibitor chloroquine, while inhibiting its degradation to trichloroacetic acid-soluble products. In our experiments, however, no intact HDL was detected in the incubation medium. It is not clear from the present studies as to which cellular compartments are involved in the preferential uptake of $\mathrm{HDL}$ cholesterol.

When luteal cells containing receptor-bound ${ }^{125}$ I-labeled HDL were chased in medium containing unlabeled HDL, the release of trichloroacetic acid-precipitable radioactivity consisting of partially degraded HDL was increased. A similar phenomenon was observed by Marshall [26] in the processing of insulin in adipocytes, where inclusion of unlabeled insulin in the chase incubation medium increased the retroendocytosis of cellbound ${ }^{125} \mathrm{I}$-labeled insulin and reduced the levels of cellular and degraded ${ }^{125} \mathrm{I}$-labcled insulin. The presence of unlabeled HDL in the medium may 
stimulate the rate of internalization and processing of the receptor-bound ${ }^{125} \mathrm{I}$-labeled $\mathrm{HDL}$ by the cell during the chase incubation. Since lysosomal degradation is not rapid enough to keep up with the influx of HDL, the partially degraded HDL is regurgitated faster. According to this mechanism, the uptake of HDL cholesterol by luteal cells is a rapid process, independent of lysosomal degradation.

Stimulation of progesterone production in luteal cells by human $\mathrm{CG}$ increases cholesterol substrate utilization, and would be expected to increase lipoprotein uptake and degradation. When we tested this possibility by adding human $C G$ to the chase incubation medium, no detectable effect of human $\mathrm{CG}$ on the composition of the radioactive products released was observed. It is possible that the cells have accumulated enough cholesterol during the initial incubation to sustain progesterone production at maximal levels, and increased steroidogenesis does not significantly deplete cellular cholesterol levels under the experimental conditions.

Based on these studies, a model for HDL metabolism in luteal cells is proposed (Fig. 8). The initial phase is the binding of HDL particles to specific receptors on the luteal cell surface. Both apolipoproteins A-I and A-II have been shown to interact with the receptors [6]. The HDL particles are then internalized, although it appears that endocytosis via clathrin-coated pits is probably not involved. Once inside the cell, cholesterol and cholesteryl esters are taken up by a process not involving lysosomal degradation. The partially degraded HDL particle is either released as such

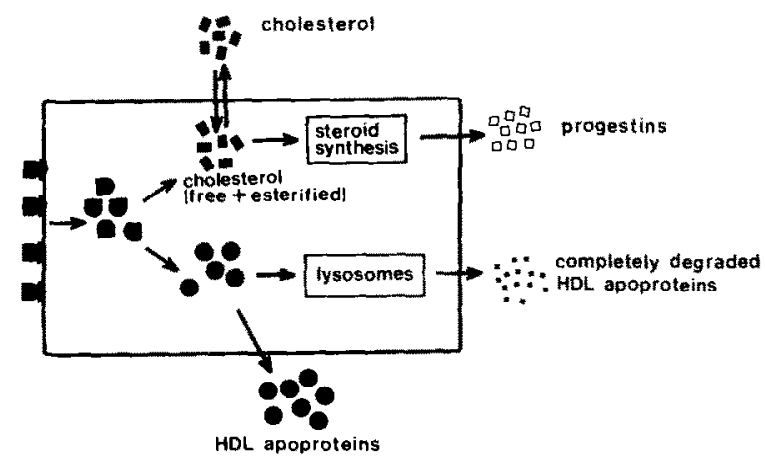

Fig. 8. Proposed mechanism of HDL metabolism in rat luteal cells. from the cell or gets trapped in the lysosomal pathway and is completely degraded. Most of the HDL-derived cholesterol is either utilized for steroidogenesis or stored in the cell, while a small amount appears to be released into the medium, which is probably due to the bidirectional flux of cholesterol. Following the intracellular processing of $\mathrm{HDL}$, the HDL receptor is likely to be recycled, although experimental evidence is not available for this at the present time.

\section{Acknowledgements}

This work was supported by National Institute of Health grant HD 06656. We thank Ms. Melissa Aceves for excellent secretarial assistance.

\section{References}

1 Azhar, S., Menon, M. and Menon, K.M.J. (1981) Biochim. Biophys. Acta $665,362-375$

2 Azhar, S. and Menon, K.M.J. (1981) J. Biol. Chem. 256, 6548-6555

3 Christie, M.H., Strauss, J.F. and Flickinger, G.L. (1979) Endocrinology 105, 92-98

4 Schuler, L.A., Scavo, L., Kirsch, T.M., Flickinger, G.L. and Strauss, J.F. (1979) J. Biol. Chem. 254, 8662-8668

5 McNamara, B.C., Booth, R. and Stanfield, D.A. (1981) FEBS Lett. 134, 79-82

6 Hwang, J. and Menon, K.M.J. (1983) J. Biol. Chem. 258, $8020-8027$

7 Hwang, J. and Menon, K.M.J. (1985) J. Biol, Chem. 260, $5660-5668$

8 Goldstein, J.L., Anderson, R.G.W. and Brown, M.S. (1979) Nature 279, 679-685

9 Brown, M.S., Anderson, R.G.W. and Goldstein, J.L. (1983) Cell 32,663-667

10 Brown, M.S. and Goldstein, J.L. (1979) Proc, Natl. Acad. Sci. U.S.A. 76, 3330-3337

11 Schreiber, J.R., Nakamura, K. and Weinstein, D.B. (1982) Endocrinolugy 110, 55-63

12 Rajendran, K.G., Hwang, J. and Menon, K.M.J. (1983) Endocrinology 112, 1746-1752

13 Rajan, V.P. and Menon, K.M.J. (1985) Endocrinology 117 , 2408-2416

14 Gwynne, J.T. and Hess, B. (1980) J. Biol. Chem. 225, 10875-10883

15 Glass, C., Civen, M., Pittman, R.C. and Steinberg, D. (1983) Arteriosclerosis 3, 500a

16 Leitersdorf, E., Stein, O., Eisenberg, S. and Stein, Y. (1984) Biochim. Biophys. Acta 796, 72-82

17 Havel, R.J., Eder, H.A. and Bragdon, J.G. (1955) J. Clin. Invest. 34, 1345-1353

18 McFarlane, A.S. (1958) Nature 182, 53

19 Jonas, A., Hesterberg, L.K. and Drengler, S.M. (1978) Biochim. Biophys. Acta 528, 47-57 
20 Bierman, E.L., Stein, O. and Stein, Y. (1974) Circ. Res. 35, 136-150

21 Rajendran, K.G., Menon, M., Peegel, H., Hwang, J. and Menon, K.M.J. (1985) Can. J. Physiol. Pharmacol. 63, $265-272$

22 Stepka, W. (1957) Methods Enzymol. III, 504-528

23 Affinity Chromatography - Principles and Methods (1983) Pharmacia Fine Chemicals, Uppsala

24 Lowry, O.H., Rosebrough, N.J., Farr, A.L. and Randall, R.J. (1951) J. Biol. Chem. 193, 265-275
25 Deacon, A.C. and Dawson, P.J.G. (1979) Clin. Chem. 25 , 976-984

26 Marshall, S. (1985) J. Biol. Chem. 260, 13524-13531

27 Filipovic, I. and Buddecke, E. (1977) Lipids 12, 1069-1077

28 Filipovic, I. and Buddecke, E. (1978) Artery 4, 243-260

29 Paavola, L.G. and Strauss, J.F. (1983) J. Cell Biol. 97, 593-606 